\title{
Effect of screening and brief intervention for illegal drug use in Southern California
}

\author{
John Clapp*, Susan I Woodruff \\ From International Network on Brief Interventions for Alcohol Problems (INEBRIA) Meeting 2011 \\ Boston, MA, USA. 21-23 September 2011
}

The California Screening, Brief Intervention, and Referral to Treatment (CASBIRT) program provided services to over 120,000 emergency/trauma patients throughout ethnically diverse San Diego County from 2007-2010. This study examined outcomes for drug users screened in emergency departments (ED) throughout the county. Universal screening using the ASSIST was offered to all capable adult patients by trained bilingual/bicultural health educators in $12 \mathrm{ED} /$ trauma centers over a three-year period. Patients who screened positive on the Alcohol, Smoking, and Substance Involvement Screening Test (ASSIST) were given brief motivational feedback/intervention matched to risk level. A random sample of patients was targeted for a follow-up telephone interview six months later. This analysis included participants who reported risky drug use in addition to risky alcohol use at their initial screening $(\mathrm{N}=1171)$. About $32 \%$ of the sample $(n=373)$ were actually interviewed by telephone at follow-up. We conducted analyses per intent to treat and recoded missing follow-up values using the "last value carried forward" approach. Half of the resulting sample of 1171 patients was male; the average age was 37 (SD = 13.3). The sample was $44 \%$ non-Latino white, $35 \%$ Latino, $15 \%$ black, and $7 \%$ other racial/ethnic groups. The substance most commonly reported was marijuana (29\%) followed by methamphetamine (13\%) and heroin (7\%). There was a significant entry-to-follow-up reduction in the percent reporting any use of illegal drugs in the past month (53\% to $38 \%, F=35.33, p<0.001$ ). Days of use of illegal drugs also showed reductions, from a mean of five days to four days $(F=63.74, p<0.001)$. These results, based on a conservative analysis approach, demonstrated that CASBIRT had a statistically significant positive effect on selfreported illegal drug use.

\footnotetext{
San Diego State University Center for Alcohol \& Drug Studies, San Diego, CA, USA
}

Submit your next manuscript to BioMed Central and take full advantage of:

- Convenient online submission

- Thorough peer review

- No space constraints or color figure charges

- Immediate publication on acceptance

- Inclusion in PubMed, CAS, Scopus and Google Scholar

- Research which is freely available for redistribution 